\title{
Resource Nationalism, Bargaining and International Oil Companies: Challenges and Change in the New Millennium
}

\author{
Dr Vlado Vivoda* \\ Research Fellow, Centre for International Risk, School of International Studies \\ A1-03, Magill Campus, University of South Australia, GPO Box 2471, Adelaide, SA 5001, Australia \\ E-mail: vlado.vivoda@unisa.edu.au \\ Tel: +61 883024874
}

\begin{abstract}
By focusing on major international oil companies (IOCs), this paper examines the balance of power in the oil industry in the current decade, which, unlike the previous two cooperative decades, can be characterised as 'conflictual'. In this decade, due to their weak relative bargaining power, the IOCs have generally been unsuccessful in bargaining with oil-exporting countries and national oil companies (NOCs). As a result, we are witnessing the return of the obsolescing bargain. Various factors endow oilexporting countries and their NOCs with increased bargaining power vis-à-vis the major IOCs. High oil prices, increased industry competition, the lack of alternative investment options for IOCs and an increasingly hostile political climate in many oil-exporting states, translate to weaker bargaining power and unfavourable outcomes for IOCs. Their future as viable business entities is further compromised by the changing policy and regulatory environment in response to global climate change. By examining the strategies that major IOCs have adopted and may adopt to deal with systemic changes in the international oil industry, this paper proposes that to ensure the majors' long-term survival and viability, home governments should assume partial control of major IOCs and thus transform them into NOC-IOC hybrids.
\end{abstract}
Keywords:
Oil Industry, IOCs, NOCs, Resource Nationalism, Bargaining
Word Count:
7,067

\section{Introduction}

The oil industry is an industry in which, typically, large economic rents can be earned, because the market price is well above the price required to keep the factor of production in active use and is above the price required to earn economic profits. Bargaining and negotiation determine the division of these rents and, historically, there has been cyclical change in the relative balance of power between host states and their NOCs and major IOCs (Stevens 2008: 27). For instance, some periods, such as the 1970s and early 1980s, can be classified as 'conflictual' as there was a high degree of disharmony between actors with incompatible interests and host states and NOCs were dominant. In contrast, other periods, such as the late 1980s and 1990s, can be referred to as 'cooperative', due to relatively harmonious relationships and compatible interests between actors in the international oil industry. This was also a period when IOCs were in a dominant position vis-à-vis the host states.

The 1970s and early 1980s saw oil produced for the international oil market progressively brought under state control. The IOCs lost control of numerous 'sweetheart' deals with oil exporting governments and their initial bargains obsolesced. ${ }^{\dagger}$ In contrast, the late 1980 s and

\footnotetext{
* The author wishes to thank A/P Terry O’Callaghan and Geordan Graetz for their feedback on previous drafts.

† The concept ‘obsolescing bargain’ was initially framed by Vernon in Sovereignty at Bay (see pp. 47-53).
} 
1990s showed an opposing development as the oil industry experienced both deregulation and privatisation (Stevens 1998: 13). The oil price drop in 1986 and the continued lower oil prices in the years thereafter unleashed a move away from the indebted state. Therefore, some states, such as the UK, Brazil, Argentina, Italy and France, privatised their oil industries. Other countries saw the need to at least commercialise state-owned oil companies and transform them into 'normal' companies (van der Linde 2000: 7-8). As government control has become less direct, NOCs attempted to redefine their roles, which occasionally put them at odds with their governments (for example the Venezuelan government versus PdVSA). A major boost in the privatisation of NOCs in the oil industry came in the early 1990s when centrally planned economies commenced a process of transition towards a market economy. The fragmentation of the Soviet Union into separate states and their painful transition to a market-based economy opened up the oil sector for private investment (Hartshorn 1993: 276). In addition, in the 1980s and 1990s, most Organisation of Economic Cooperation and Development (OECD) governments increased oil taxation and, thus, captured an increasing share of economic rent, which was diverted primarily away from producer governments. Arguably, IOCs, after a period of 20 years, resumed a dominant role in the international oil industry, as their market control had increased and joint ventures, strategic alliances and mergers had served to balance risk and control (van der Linde 2000: 8).

Resource nationalism and the 'obsolescing bargain' of the 1970s weakened by the mid-to-late 1980s and 1990s. Morse (1999: 14) argued that in the 1990s, 'resource nationalism has practically disappeared from the discourse of international relations.' In line with general trends and with low oil prices in the 1990s, various oil-exporting states offered relatively attractive deals to major IOCs, although these were short of the deals offered during the concessions era. The reopening of reserves to foreign companies took various forms in different countries. Terms on which foreign oil companies invested in host countries varied considerably, from royalty/tax system, which was most favourable to the IOCs, to PSAs and risk service agreements, which were least favourable for the IOCs. In the 1990s, host countries needed the investment and IOCs wanted access to oil, but only if it had been cheaper to produce than elsewhere.

Three basic underlying factors influenced the relative balance of power in the oil industry in the second part of the 1980s and in the 1990s. First, low oil prices resulted in host countries' desperate need for foreign investment. Second, IOCs had no competition from other companies, such as oil-importing NOCs, when investing in host countries. Third, IOCs were able to pursue alternative investment options if not permitted favourable entry to a particular host state. Thus, in the late 1980s and 1990s, bargaining in the international oil industry took place largely between various oil-exporting states and not between oil exporters and IOCs.

The aim of this paper is to analyse the changing balance of power in the contemporary international oil industry with particular focus on five major IOCs (BP, Chevron, ExxonMobil, Royal Dutch/Shell and Total) and, based on this, to assess the viability of future options for the majors. It is argued that the oil industry has shifted from a cooperative phase in the 1990s, when the IOCs managed numerous 'sweetheart' deals, to a 'conflictual' phase characterised by resurgent resource nationalism and re-obsolescing bargains for IOCs in the current decade. Although the majors have made unprecedented profits in recent years and have had considerable return on investment, this does not infer that they have been successful. High oil prices have endowed oil-exporting states with increased bargaining power, which has been the main driver behind the resurgence in resource nationalism. The majors have also been faced with a high degree of industry competition from NOCs in 
particular. As a result, the majors have struggled to secure access to new oil reserves and their production has dropped in recent years. Their problems are exacerbated by the forthcoming changes in climate change mitigation policy and the regulatory environment in many states, which are likely to further damage their future viability. The consequences and future implications of systemic changes in the international oil industry for major IOCs and possible business strategies that they may employ to deal with the changes are also analysed. It is argued that the events in this decade may signal the looming and, most likely, definitive demise of some of the major IOCs, which were once dominant players in the international oil industry. It is proposed that one way to salvage the majors in the long-term would be for their home governments to assume partial control, thus creating NOC-IOC hybrids, which may be more resilient in dealing with the challenges.

\section{Underlying Challenges}

\section{Resource Nationalism and the Petro-Political Cycle}

Resurgent resource nationalism in the oil industry represents the underlying factor behind the demise of major IOCs in this decade. The main reason for this resurgence has been the high price of oil. When oil prices are low, as in the late 1980s and for much of the 1990s, IOCs are courted by commodity-rich states to develop their national resources. However, when prices rise, as they did in the early years of the new millennium, host governments rethink their contracts and seek higher taxes and royalties. Thus, it is natural that during a period of high prices the phenomenon of resource nationalism returns, as it is a by-product of high prices (Wälde 2008: 56). This state of affairs corresponds to Wilson's model of the politics of the world oil market - the petro-political cycle (PPC) (Wilson 1986: 7-19; 1987: 144-7). The PPC model posits that the likelihood and the direction of market politicisation are a direct function of the boom-and-bust phase of that market; thus, petro-politics at the peak of the market will differ substantially from politics in the trough. In rising markets, sellers, such as oil-exporting governments, gain leverage; in falling markets, buyers, such as IOCs or oilimporting governments, gain leverage. In addition, in times of rising prices, governments of developing states, which occupy a subordinate position in the international system, have real incentive to alter the basic rules of the game and reverse this status quo (Wilson 1987: 145).

Governments of Latin American states, such as Venezuela, are 'old hosts' to FDI and have much experience with multinationals. Rapid privatisation of key politically sensitive sectors in Latin America in the 1990s caused a backlash from governments and the general public as the number of foreign takeovers increased. The openness to FDI in Latin America in the 1990s generated sufficient resentment required to swing the pendulum in the other direction. Whereas MNCs in general were offered subsidies and tax cuts to invest in Latin American economies in the 1990s - for instance, one per cent royalties paid by IOCs producing in Venezuela's Orinoco Tar Sands - these generous terms have been eliminated and governments are increasingly regulating their politically sensitive industries. In the current decade, Chàvez has marginalised the private sector by changing Venezuela's hydrocarbon legislation. The heavy-oil projects, which were previously under private control, have fallen under state control (Vivoda 2008: 97-117). Besides the oil industry in Venezuela, increased regulation and/or nationalisation followed in Bolivia and Ecuador. For instance, in May 2006, Bolivian President Evo Morales nationalised Bolivia's oil and gas assets and Ecuador joined its Latin American neighbours when it seized an oil field controlled by Occidental, a USbased IOC. 
The Russian Federation, a transition economy, has little experience with inward FDI, similar to other transition economies. In the 1990s, following the collapse of communism, Russia's economy opened to investment, which has been an important component of the economic reform program. Its initial openness, evident in pro-FDI policies and privatisation, was 'the calm before the storm', which started with former President Putin's crackdown on Yukos in mid-2003. What followed was a renationalisation of much of Russia's oil industry, increased regulation and higher taxes and an increasingly anti-FDI climate, as Russia retreated from liberalisation and returned to high levels of state control. By understanding how important it is for a transition economy to control its oil industry, given that relying on global market forces alone did not serve its interests, Russia has quickly learnt how to deal with the presence of IOCs. Putin understood that the goals and interests of IOCs do not fully coincide with those of Russia and, thus, the door has been closed for major IOC participation in its oil industry. Thus far, Putin has largely accomplished his goal of renationalising hydrocarbon resources and legislation introduced in 2005 made foreign investment in the country's most geologically attractive areas much more difficult (Vivoda 2008: 64-80). In addition, in January 2004, a similar development occurred in Kazakhstan, another former Soviet republic and now transition economy, which toughened its contract terms, limited foreign ownership in ventures, removed tax stability clauses and introduced a new escalator tax (Shelley 2005: 144).

The resurgence of resource nationalism is not confined to Latin America and the former Soviet Union. In Angola, Nigeria, Chad, Sudan and elsewhere, local protests for a greater share in the nation's oil wealth have disrupted production frequently. Nigeria and Angola have linked access to upstream assets to investments in other parts of the economy and have continued to demand large signature bonuses. In virtually every oil-exporting country, NOCs, which had in the 1990s ceded ground to IOCs in the wake of globalisation, have reclaimed lost ground. The majors are struggling to hold on to their position in most states in which they operate (Johnston 2008: 38). There is a balance of power between governments and firms determined by the particular circumstances of the times. In the current decade, when considering exclusively empirical evidence from the oil industry, the nation-state appears robust as a regulator of MNCs. There is no evidence to demonstrate that, in the first decade of the new millennium, governments are fading away in the face of the power of IOCs. On the contrary, IOCs' bargaining power is fading away vis-à-vis that of host states. Resource nationalism is back at the forefront of relations between host-governments and IOCs and it 'translates into an anti-Western IOC campaign' (Stevens 2008: 26). Some claim that despite the existence of 'some holdout governments that refuse to relinquish control to the private sector,' resource nationalism is moribund (Morse 1999: 18). This does not apply in the oil industry, where oil producing and exporting states own and control between 77 and 90 per cent of total proven world oil reserves (Marcel 2006: 1; Chen and Myers Jaffe 2007: 11; Myers Jaffe 2007: 1). The IOCs’ bargain has obsolesced once again.

As a result of resurgent resource nationalism, IOCs are not welcome in the major oilproducing region of the world, the Middle East and also in North Africa and much of Latin America. If they are present in some states in these regions, it is usually, as in the case of Iran, under unfavourable investment conditions. Africa, the former Soviet Union, the Middle East and Latin America, regions in which IOCs most want to operate, are extremely difficult operating environments due to political and regulatory constraints. Much of the majors' production comes from the North Slope in Alaska, the Gulf of Mexico and the North Sea, areas which are in a phase of rapid decline and where production is becoming increasingly cost prohibitive. North America and the North Sea account for 60 per cent of the majors' oil 
production and these are the regions where more than 50 per cent of the reserves have been extracted. In those areas, production costs continue to climb and every new investment to extend the life of the reservoirs becomes more marginal, as fixed costs are covered by shrinking volumes. In the North Sea, the average extraction cost for a barrel of oil increased by 42 per cent from 2000 to 2005 (Bozon et al. 2005). Other states and 'safe zones' that are open to IOC investment are those in which, due to technical challenges, production is profitable only if oil prices remain very high (Alberta, Siberia, offshore West Africa), or in alternative energy sources (oil shale, tar sands, renewable). Many of these options represent high risk to major IOCs as they may be unprofitable in the medium-term if oil prices fall further. Moreover, increased industry competition further reduces their access to reserves. As a result, major IOCs have full access to countries with only 6 per cent of the globe's known reserves, mainly in North America and Europe and can also invest in countries that own an additional 11 per cent of reserves through JVs or PSAs (Mouawad 2006).

\section{Industry Competition}

Major IOCs also face increasing competition. NOCs have grand ambitions and compete with the majors by developing new oil reserves overseas and investing in international refining and retail activities with a long-term business perspective (Marcel 2006: 72-3). Technology, capital and access to markets, the lack of which was often seen as a reason to privatise NOCs, are now easily available from independent operators (Talisman Energy and Apache) and oilservice companies (Halliburton and Schlumberger), but, most importantly, from NOCs from oil-importing (China, India, Brazil) and -exporting countries (Malaysia, Norway, Saudi Arabia), which are expanding internationally and competing with major IOCs. Competition for untapped energy deposits with NOCs from China and India has been described as 'fiercer than ever' (Bozon et al. 2005). For instance, Chinese NOCs have in recent years spent billions of dollars on a global scramble for oil to feed China's booming economy. They have the ability to obtain government loans at little or no interest. The Government's energy security policy is aimed at developing multiple import sources and routes and building up reserves to avoid unexpected interruption (Xu 2006: 273-4). Driven by the Government's policy, China's NOCs have acquired growing equity oil stakes and long-term crude oil contracts and have signed 'strategic' alliances with oil producers in all of the world's major oil-producing regions. In doing so, they have emerged victorious vis-à-vis major IOCs in various bidding and bargaining episodes and have provided IOCs with unwanted competition in many oil-producing countries, particularly in Angola, Iran, Kazakhstan, Nigeria and Venezuela.

\section{Exogenous Challenges: The Uncertain Climate Change Policy Environment}

It is important to highlight a significant future challenge to IOCs, which is exogenous to the international oil industry, but when paired with the endogenous challenges outlined above, it makes the future even more uncertain for major IOCs. Climate change mitigation is becoming one of the principal challenges for major IOCs and emissions-intensive firms in general. Reliance on oil, coal and gas as primary sources of energy has left the world with a legacy of environmental issues such that we now live in a climate constrained world (Jaccard 2005). It is now generally accepted that we are in the midst of a climate crisis (Stern 2006; Garnaut 2008). Carbon dioxide $\left(\mathrm{CO}_{2}\right)$ emissions are causing the planet to warm with potentially devastating consequences and climate change is recognised as 'the gravest danger to humanity' (Mattoo and Subramanian 2009: 23). According to specialists, government regulation is essential in achieving the 'decarbonisation' of economies (Beerepoot and 
Beerepoot 2007). Former US Vice-President Gore (2007) believes that the situation is so dire that the US must generate 100 per cent of its electricity from renewable sources within ten years. While his prediction may be alarmist, what is not in doubt is that the world needs to transition away from its reliance on fossil fuels toward renewable and less emissionsintensive sources of energy. There is currently much uncertainty over the possibility of new or strengthened policies to mitigate climate change and an increase in the pace of energy transition. However, any new regulations to limit greenhouse gas emissions will have a significant impact on energy production and consumption (Securing America's Future Energy 2008: 3) and on the oil industry, which 'will be severely affected by regulatory measures’ (Skjærseth and Skodvin 2001: 44).

New and strengthened climate change mitigation policy and regulatory environments, which serve as bases for an accelerated energy transition in which fossil fuels and, particularly, oil, play a less pronounced role, are likely to carry negative consequences for major IOCs and other producers of energy sources being replaced. For IOCs, climate change mitigation regulation is likely to be strongly felt on their downstream operations, which in 2007 accounted for 21 per cent of the world's refining throughputs (BP 2008: 18; OPEC 2008: 121). Oil refineries are financially risky projects long-term. Facing significant regulatory risk, it has become more difficult for IOCs to justify significant downstream infrastructure investment in projects that may, due to a changing regulatory environment, cease to be viable before they are even completed (Securing America’s Future Energy 2008: 3).

Historically, American oil companies have been key players in limiting the enactment of domestic energy and environmental policy aimed at curbing fossil fuel use and, consequently, the US government's ability to manage petroleum demand has been severely restricted (Goel 2004: 467). In recent years, however, the oil majors have perceived of climate change to be major threat (Levy and Kolk 2002: 296), and have made considerable shifts in their corporate climate strategies away from active denial (Kolk and Levy 2001: 501; Andreassen Sæverud and Skjærseth 2007: 49-50), but their responses have lacked objective assessment of underlying policy and regulatory change in the US and other markets. This lack of attention to looming policy changes may further threaten their future as viable business entities. Of particular concern for the oil majors is the new Obama administration's commitment to climate change mitigation and their rapid action on greenhouse emissions (Lite 2009).

\section{Consequences for Major IOCs}

Recent developments in the international oil industry have had a negative effect on the health of IOCs as viable business entities and this section explores the consequences. Ostensibly, it is hard to believe that major IOCs may be facing difficult times ahead. In 2007, ExxonMobil reported the largest profits in the corporate history, US\$40.6 billion. Also, in 2007, the combined sales revenues of ExxonMobil, BP, Royal Dutch/Shell, Chevron and Total amounted to US\$1.47 trillion, a sum greater than the GDP of Spain or Canada and their combined profits amounted to over US\$122 billion, a sum equivalent to the GDP of Egypt or New Zealand (IMF 2008; OPEC 2008: 122-4). Moreover, in 2007, the five major IOCs earned a 20 per cent return on investment, a healthy figure by industry standards. Given such impressive figures, why would one need to be concerned about their future? Without doubt, high oil prices have assisted major IOCs in generating unprecedented profits. At the same time, however, high oil prices have fuelled the resurgence of resource nationalism, which paired with increased industry competition severely limits areas open to IOC investment and has had negative effects on their operations. It is becoming increasingly difficult for IOCs to 
find attractive ways to reinvest their profits and it will not get easier given that there are limited drilling prospects. Buried beneath their record profit figures of recent years are worrying signs of a sector in decline.

\section{Declining Reserves and Production}

Although the major IOCs are highly liquid due to the surge in the price of oil in recent years, the lack of investment opportunities represents a challenge as they have been unable to replace their reserves in recent years. In the oil industry, 'reserve replacement is the best guide to whether a company will be able to maintain - or grow - production in the future' (Schwartz 2006a: 12). A healthy reserve replacement ratio should always be over 100 per cent. Between 1998 and 2002, the five majors 'replaced' 99.7 per cent of oil produced, which was at the 'break-even' point. However, a composite ratio for five major IOCs has been below that level in recent years. Between 2003 and 2007 they 'replaced' only 51.7 per cent of oil produced (OPEC 2003: 124; OPEC 2008: 121). In 2004, Royal Dutch/Shell's announcement that it had revised down their proven oil reserves by 20 per cent suggested that oil majors have faced significant difficulties in booking new reserves. Their poor reserve replacement performance is in contrast to the 1970s and 1980s when strong IOC exploration spending spurred a large increase in non-OPEC production, promoting diversity of supply and enhancing US energy security for two decades (Myers Jaffe and Soligo 2007: 4). These non-OPEC assets are now moving toward natural, geologic decline. Given the recent trend, and rising political and legal hurdles to their investment in OPEC and other non-Western countries, it is expected that their composite reserve replacement ratio will remain well below 100 per cent over the next five to ten years as the five majors face increasingly difficult challenges finding new sources of oil to replace existing reserves.

The biggest obstacle the majors face in replacing their reserves is the ultimate peculiarity of the oil business. Oil is the only industry in which the cheapest to produce oil reserves and largest assets, those located in Russia and OPEC states are not in the hands of the most efficient and best-capitalised firms, the oil majors. Instead, they are controlled by NOCs, and in most cases the government owns and self-finances the whole operation from reserves to pipelines. As illustrated in the previous section, in numerous states, foreign investment in oil exploration and production (upstream) activities is banned or saddled with strong disincentives. Desperate majors have been looking for growth in West Africa, the Caspian, Russia's Far East, Canada's tar sands and the ultra-deep waters off the coastal Brazil. Nevertheless, this new wave of oil exploration is proving difficult and dangerous, due to complex oil formations and unforgiving environments that require much up-front capital expenditure and due to unreliable legal frameworks and political risks associated with investing in some of these states. As a result, analysts have suggested that 'Big Oil confronts its most far reaching test in decades' (Bozon et al. 2005).

As a consequence of their inability to replace reserves, the five majors' booked oil reserves, oil production and Reserve-to-Production (R/P) ratio have all plunged (see Table 1). For instance, their booked oil reserves dropped by 23 per cent between 2002 and 2007 and their $\mathrm{R} / \mathrm{P}$ ratio plummeted from 10.5 years to 8.3 years during the same period. In contrast, the top ten NOCs in 2006 have had R/P ratio of 78 years (Pirog 2007: 3). Moreover, major IOCs' composite oil production dropped by 5.3 per cent between 2004 and 2007. In 2007, they owned 2.5 per cent of the world's total oil reserves (down from 3.7 per cent in 2000), and in the world's list of top twenty oil companies by reserves in 2006, ExxonMobil was fourteenth, the top ranked major (Pirog 2007: 3). In 2007, the five majors produced only 38 per cent of 
their sales volume and 12.4 per cent of global oil production (BP 2008: 8; OPEC 2008: 121). In contrast, in 1972, the majors controlled 91 per cent of Middle Eastern production and 77 per cent of the non-communist world's oil reserves outside the United States (Bromley 2005: 230 ) and until 1970, integrated trading represented 85-90 per cent of international oil trade (Noreng 2002: 164).

Table 1: Major IOCs’ Composite Oil Reserves, Production and R/P Ratio (1998-2007)

\begin{tabular}{|l|c|c|c|c|c|c|c|c|c|c|}
\hline & 1998 & 1999 & 2000 & 2001 & 2002 & 2003 & 2004 & 2005 & 2006 & 2007 \\
\hline Reserve size (billion $\mathrm{bbl}$ ) & 40.6 & 40.9 & 41.1 & 38.6 & 39.9 & 38.9 & 34.7 & 33.3 & 32.5 & 30.7 \\
\hline Production (mil. bpd) & 10.5 & 9.4 & 10.2 & 10.1 & 10.4 & 10.4 & 10.7 & 10.4 & 10.3 & 10.1 \\
\hline R/P ratio (years) & 10.6 & 12.0 & 11.1 & 10.5 & 10.5 & 10.2 & 8.9 & 8.8 & 8.6 & 8.3 \\
\hline
\end{tabular}

Sources: OPEC, 2003: 125-7; OPEC, 2008: 122-4.

\section{Returns on Investment (ROI)}

As a result of high oil prices, in recent years, major IOCs have been generating unprecedented profits and have had positive returns on investment since 2003. 2005 was a particularly healthy year for the five majors, as they earned over 50 per cent return on investment. Between 2005 and 2007, however, although their profits increased by 11 per cent, their composite ROI had dropped to 20 per cent (OPEC 2008: 122-3). In the capitalintensive oil industry, return on investment is a key measure as it reflects not just how much profit a company made, but the cost of making it. The bottom line is that value creation by oil companies is stagnating. While IOCs are profiting more than ever before, they are also spending unprecedented amounts to generate those profits. The majors are affected by rising costs in exploration and extraction. The cost of labour, supplies and, as a direct consequence of high oil prices, the energy needed to explore for and produce oil, are all soaring, driving up the investment needed to find and develop new fields (Knight 2008). Moreover, due to government-imposed constraints in many oil-producing regions, major IOCs are struggling to find where to put their profits to work in order to increase their return on investment in the future. As a result, given the lack of new investment opportunities, in 2006, the five majors used 56 per cent of their operating cash flow to buy back stock and return money to stockholders through dividends (Securing America’s Future Energy, 2008: 1-2).

\section{The Future: Weathering the Storm?}

The major IOCs are unable to effectively address the serious issues caused by the resurgence in resource nationalism, magnified by the looming energy transition and changing policy environment. They face a variety of problems: booking additional reserves; protecting future demand for hydrocarbons; responding to new environmental regulations in the consuming countries; and responding to increasing competition from NOCs and service companies. In order to remain viable business entities in the coming decade, major IOCs need to increase their reserve base and oil production in order to grow profits. However, in future, the industry environment is set to become even more challenging for the IOCs. The rise of the NOCs and resource nationalism will ensure that the major IOCs will not be able to secure favourable deals in future. In addition to political and legal barriers to investment, it has become increasingly difficult for IOCs to provide a value proposition to the owners of natural resources, unless it is for the most technologically complex resources (Oxford Analytica 2008) and some have suggested that even these areas are no longer exclusively theirs (Johnston 2008: 31-2). The adverse impacts are likely to destabilise and undermine their future viability as business entities. As a result, Stevens (2008: 25) argues that the next fall in oil prices will cause another round of mega-mergers among the IOCs and that large IOCs 
may even disappear. This section examines the strategies that major IOCs have employed, or may employ in the future, in order to weather the storm.

The emerging trend of downstream and upstream internationalisation of NOCs is particularly threatening for major IOCs. The NOCs are challenging the IOCs on their own turf, as most NOCs now have international activities. As a result, there has been a blurring of categories between IOCs and NOCs, as many NOCs see themselves as 'hybrids' (Marcel 2006: 56 and 70) and are increasingly competitive with IOCs. This is exacerbated by NOCs' access to cheap home government finance, which provides them with unfair advantage vis-à-vis major IOCs in bidding for concessions. One possible strategy to make IOCs more competitive would include major IOCs' home governments, particularly governments in the US and the UK, taking partial control of IOCs based in their countries, transforming them into IOC-NOC hybrids.

The idea of western oil-importing governments partially nationalising and/or protecting their IOCs is not new. For instance, the United States came close to creating its own NOC during World War II. The Petroleum Reserves Corporation was promoted by Secretary of the Interior Harold Ickes and supported by the military as a means to ensure access to foreign oil reserves (particularly in Saudi Arabia) through direct ownership by the US government (Yergin 1992: 397-9). While not directly recommending government ownership of oil majors, Krasner (1978: 39 and 336-7) argued that the state should try to maximise its control over foreign sources of oil by protecting the investment activities of its own oil companies, even through the employment of force. Moreover, Noreng (1981: 141-2) argued that French, Italian, Norwegian and British NOCs, unlike IOCs, were operating under a raison d'être that largely carried them above market forces, as they were able to mobilise funding in the event of poor judgment. These NOCs were not subject to the same set of sanctions as the IOCs, since, if the latter erred in judgment by expanding too fast or misusing funds, they were punished by the market. Hence, they have had to reduce their rate of growth or, in extreme situations, declare bankruptcy. Consequently, Western NOCs permitted themselves greater risk and higher rates of growth than IOCs, thus paying less attention to the most efficient use of resources and capital in deference to other goals.

The idea of a US NOC has been revisited in recent years. Although it has been deemed radical and unlikely, it is argued that benefits would include a more direct linkage between oil and US government interests and that a US NOC would respond more directly to energy policy directions established by the government, thus improving US energy security (Pirog 2007: 15). At the same time, a government-controlled oil company would gain from home government support. Historically, the interests of American IOCs and the US government have not been exclusively aligned. Even when they were aligned, the US government did not always support American IOCs in bargaining and negotiations with other actors (Vivoda 2008: 190-1). This was most likely the case because major IOCs have historically had substantial bargaining leverage in their own right and required little explicit intervention by the US government (Myers Jaffe and Soligo 2007: 31). However, as argued in this paper, they have lost their bargaining advantage vis-à-vis oil-exporting states and NOCs in the current decade.

Pirog (2007: 16) and Myers Jaffe and Soligo (2007: 33) suggest that the most persuasive reason for not creating a US NOC is that the private IOCs are very effective in terms of efficiency and productivity in finding and developing new oil resources and that their performance has been impressive. This argument, however, does not reflect the reality in the 
international oil industry given that major IOCs' reserve replacement ratios in the past five years have been inadequate. Thus, it is reasonable to suggest that Western governments should consider intervention and partial ownership of major IOCs. The bottom-line is that market forces and private enterprise do not appear to be the appropriate instruments for solving oil majors' problems in the current decade. Establishing hybrids, or increasing government intervention, could help alleviate these problems. For instance, the political support Chevron received from the US Congress in 2005 when it bid for UNOCAL ensured its success against CNOOC, which could bid higher due to its access to cheap loans from the Chinese government (Vivoda 2008: 122-31).

It has been suggested that oil companies with diplomatic support from their home governments could resist being forced out of existing contracts (Jenkins 1986: 139-65; and Tétreault 1995: 200-2). Thus, it is likely that hybrid and partially government-controlled IOCs would be more successful in their bargaining with Central Asian and African countries, which are not fully closed to foreign investment. The majors could also tap into their home governments' diplomatic expertise when dealing with host states and avoid failure caused by some executives' inadequate approach to corporate diplomacy. For instance, in recent years, ExxonMobil has been particularly disadvantaged when dealing with oil-exporting governments as it developed a reputation for arrogance under the lead of Lee Raymond that at times alienated host governments. In Russia, Raymond's high-handed manner in pursuing Yukos without government blessing offended Putin. Raymond's abrasive style also reportedly offended Saudi Arabia's oil minister resulting in the failure to secure a sizeable investment deal (The Economist 2005: 90). Home government control over IOCs would likely increase IOCs' future chance of success in improving upstream positions and maintaining old overseas markets and establishing new ones. Their interests would be more closely aligned and the IOCs would be directly supported by their powerful home governments. This would in turn help Western hybrids to reduce operational imbalances, provide a basis for future cash flow and profits and reduce the political power of the NOCs. Given the suggestion that 'it is impractical for the US government to reverse the trend toward national control [of the oil industry]' (Deutch et al. 2006: 49) then why would the US government not join this trend?

Gorst (2007: 2) argues that Lukoil, a private Russian oil company, which has always acted in close coordination with the government, often presenting itself as a faithful servant of state, 'could become a model for international majors seeking to redefine themselves and their roles in the new global landscape where state oil companies are gaining precedence over private ones.' Lukoil is the only Russian oil company to have built up a diversified business empire that now spans the globe and selection of foreign assets has been in part driven by state interests. The company has interests in the Caspian, Middle East, Central Europe, North Africa and North and South America. This unique international portfolio allows Lukoil to serve as an oil ambassador for the Russian government overseas. Unlike those of major IOCs, in recent years, Lukoil's oil reserves increased steadily and their access to markets improved dramatically (Gorst 2007: 9-10).

If home governments do not assume greater control of major IOCs, an alternative means to survive and to remain internationally competitive may be to resume mergers and thus increase industry consolidation. In the short-run, larger units would be capable of competing globally, since the bigger the player, the more likely it is to succeed when contract negotiations become increasingly difficult. However, mergers are often associated with firms in a declining, mature industry and are defensive, short-term measures. Moreover, the wave 
of consolidations in the 1990s of the largest publicly traded IOCs has not led to related success in completion of large and complex oil projects and reduction in cost of these projects (Parra 2004: 324-6; Myers Jaffe and Soligo 2007: 7-8, 10-1). Access to additional oil reserves, the fundamental problem encountered by the majors in this decade, would thus not be solved by a new wave of mergers. Mergers would also make the industry more concentrated, potentially creating an issue with antitrust regulators. While mergers may be effective as short- to medium-term solutions, they are not going to be effective in the longrun.

Alternatively, if they do not merge, or fall increasingly under control of their home governments, it is possible that the majors may 'atomise' and turn into a number of 'niche' non-integrated companies, which would concentrate on specific products or pieces of the value chain, similar to service companies (Verleger 2006/2007: 39). If this were the case, IOCs would act as service subcontractors to NOCs (Myers Jaffe and Soligo 2007: 11). By focusing on fewer aspects of the oil business, they would have a less complex balance of costs and risks to manage. However, whether they resume mergers or become niche companies, IOCs will most certainly play a diminished role in the future of the international oil industry.

Finally, entry into alternative and renewable energy is another strategy for major IOCs. Driven by the pressure to replace reserves, many of the major IOCs, except for Exxon Mobil, have been diversifying their businesses in response to the unfavourable industry context. Royal Dutch/Shell's expensive and challenging Sakhalin gas project, Shell's and Chevron's multibillion-dollar investments in Canada's oil and tar sands, BP's entry into solar power and hydrogen projects and various companies' entry into biofuels, are all reflections of IOCs' desperation. These investments were driven by the belief that high oil prices were here to stay. However, biofuels, tar sands and shale oil are much more expensive to exploit than conventional oil pumped in OPEC and many non-OPEC states. The oil price at which biodiesel is economically viable is $\$ 80$ a barrel, for US corn-based ethanol it is $\$ 60$ a barrel, for shale oil it is $\$ 50$ a barrel, while for Canadian tar sands, Brazilian cane-based ethanol, gas-to-liquids and coal-to-liquids it is $\$ 40$ a barrel (The Economist 2006: 67). Analysts from McKinsey \& Company have warned that dangers await companies that have placed too large a bet on a fundamental structural change by investing in projects that will be profitable only if the oil market has altered for good (Dobbs et al. 2006). Moreover, business history suggests that firms in 'maturing' industries do not easily adapt to new substitutes (Myers Jaffe and Soligo 2007: 11).

If diversification into alternative energy continues at this fast pace, ExxonMobil may be the only major IOC to survive. Rather than spending extra cash on projects that require high oil prices, the company has been resisting the pressure to invest more. When asked why ExxonMobil was spending so little on alternative sources of energy, such as ethanol, the CEO Rex Tillerson, said, 'We are investing heavily in conventional oil and natural gas, which is the business we are in. We are not in those other businesses' (Schwartz 2006b: 53). It is clear that ExxonMobil executives have been reluctant to empty their coffers for new development, fearing that prices will trend lower in the future and negatively affect their profit margins.

It is in the interests of home governments to rescue the majors. A partially governmentcontrolled oil company would respond more directly to energy policy directions in their home countries, thus improving their energy security. Since unstable supplies and prices can upset the general functioning of oil-importing economies and strain the political system it would be 
prudent for home governments to protect and/or control their IOCs. IOCs' home governments also profit handsomely from the majors' tax contributions, which provide further incentive to protect them. Between 1980 and 2005, oil companies directly paid or remitted more than US\$2.2 trillion in taxes, after adjusting for inflation, to US federal and state governments, including excise taxes, royalty payments and state and federal corporate income taxes. That amounts to more than three times what they earned in profits after tax during the same period and these figures do not include local property taxes, state sales and severance taxes and onshore royalty payments (Williams and Hodge 2005). In 2007, ExxonMobil paid US\$29.9 billion in income taxes, up 28 per cent over 2005, while their profits have only increased by 12 per cent over the same time period. They have also paid US\$72.7 billion in sales and other taxes in the same year (ExxonMobil 2008: 38). Moreover, major IOCs are owned by the shareholders, the vast majority of whom are 'middle class' individuals holding shares through pension and mutual funds (Shapiro and Pham 2007: 3). Given that most of the majors' profits go to the middle-class households with mutual fund investments, pension accounts and other personal retirement accounts, if any of the majors suffer, so will the average household. Thus, the majors are strategically and financially important for home governments and for their citizens. It is in their interest to take partial control of these corporations in order to ensure their long-term survival.

\section{Conclusion}

Enterprise resilience is a firm's 'ability and capacity to withstand systemic discontinuities and adapt to new risk environments' (Starr et al. 2003: 3). Firms which are able to build resilience are able to minimise these discontinuities and gain a competitive advantage in their particular market. For major IOCs, in order to remain viable business entities, it is essential to establish greater resilience in light of recent systemic changes in the international oil industry and uncertain policy environment. In this decade, the majors have been unable to effectively address serious issues caused by the resurgence in resource nationalism and magnified by the looming energy transition. The adverse impacts are threatening the continuity of their operations and undermining their future viability as business entities. Major IOCs lack resilience, as they are unable to align their corporate strategies in such a way that it is able to adjust to systemic changes in the international oil industry and a continually evolving risk environment. They are also unable to identify and develop new income streams and markets, as well as put in place effective governance structures to meet the challenges posed by an evolving risk environment.

By focusing on major IOCs, this paper examined the balance of power in the oil industry in the current decade, which was characterised as conflictual. Due to their weak relative bargaining power, in the current decade, the IOCs have been unsuccessful in bargaining with other major actors. High oil prices, increased industry competition from NOCs in particular, the lack of alternative investment options for IOCs and an increasingly antagonistic political climate in many oil-exporting states translate to weaker bargaining power and unfavourable outcomes for IOCs. Their future as viable business entities is further compromised by the looming changes in policy and regulatory environments in many states in response to climate change. By examining the strategies that major IOCs have adopted and may adopt to deal with systemic changes in the international oil industry, the paper proposed that the majors lack resilience to survive on their own in the long-term. One way in which to ensure their long-term survival and viability may be if home governments take partial control of the majors and thus transform them into NOC-IOC hybrids. This strategy would be particularly beneficial for home governments. 


\section{References}

Andreassen Sæverud, I. and Skjærseth, J.B. (2007), 'Oil Companies and Climate Change: Inconsistencies between Strategy Formulation and Implementation?', Global Environmental Politics, 7 (3), pp. 42-62.

Beerepoot, M. and Beerepoot, N. (2007), 'Government Regulation as an Impetus for Innovation: Evidence from Energy Performance Regulation in the Dutch Residential Building Sector', Energy Policy, 35 (10), pp. 4812-25.

Bozon, I.J.H., Hall, S.J.D. and Øygard, S.H. (2005), 'What’s Next for Big Oil?’, The McKinsey Quarterly, 2.

British Petroleum (2008), BP Statistical Review of World Energy 2008, June.

Bromley, S. (2005), 'The United States and the Control of World Oil', Government and Opposition, 40(2): 225-55.

Chen, M.E. and Myers Jaffe, A. (2007), 'Energy Security and National OilCompanies', The Whitehead Journal of Diplomacy and International Relations, 8 (1), pp. 9-21.

Deutch, J., Schlesinger, J. and Victor, D.R. (2006), 'National Security Consequences of U.S. Oil Dependency’, Council on Foreign Relations (CFR), Independent Task Force Report, no. 58.

The Economist (2005), 'Life after Lee', The Economist, 24 December.

The Economist (2006), 'Steady as She Goes’, The Economist, 22 April.

Dobbs, R., Manson, N. and Nyquist, S. (2006), 'Capital Discipline for Big Oil', McKinsey on Finance, vol. 18, Winter.

ExxonMobil (2008), '2007 Summary Annual Report'. Available from: http://www.exxonmobil.com/corporate/files/news_pub_sar_2007.pdf [Accessed 4 Feb 2009].

Garnaut, R. (2008), 'Garnaut Climate Change Review’, 30 September. Available from: http://www.garnautreview.org.au [Accessed 11 Dec 2008].

Goel, R. (2004), ‘A Bargain Born of a Paradox: The Oil Industry’s Role in American Domestic and Foreign Policy’, New Political Economy, 9 (4): pp. 467-88.

Gore, A. (2007), 'A Generational Challenge to Repower America', speech at the D.A.R. Constitution Hall. Washington, D.C., 17 July.

Gorst, I. (2007), ‘Lukoil: Russia’s Largest Oil Company’, Paper prepared in conjunction with an energy study sponsored by Japan Petroleum Energy Center and the James A. Baker III Institute for Public Policy, Rice University, March.

Hartshorn, J.E. (1993), Oil Trade: Politics and Prospects (Cambridge: Cambridge University Press). 
International Monetary Fund (2008), 'World Economic Outlook Database', October. Available from: http://www.imf.org/external/pubs/ft/weo/2008/02/weodata/index.aspx [Accessed 3 Feb 2009].

Jaccard, M. (2005), Sustainable Fossil Fuels: The Unusual Suspect in the Quest for Clean and Enduring Energy (Cambridge: Cambridge University Press).

Jenkins, B. (1986), 'Re-Examining the 'Obsolescing Bargain:’ A Study of Canada’s National Energy Program’, International Organization, 40 (1), pp. 139-65.

Johnston, D. (2008), 'Changing Fiscal Landscape', Journal of World Energy Law \& Business, 1 (1), pp. 31-54.

Knight, C. (2008), 'Despite Record Profits, Oil Companies Find Little Comfort in High Prices', International Herald Tribune, 17 February.

Kolk, A. and Levy, D.L. (2001), 'Winds of Change: Corporate Strategy, Climate Change and Oil Multinationals', European Management Journal, 19 (5), pp. 501-509.

Krasner, S.D. (1978), Defending the National Interest: Raw Materials and US Foreign Policy (Princeton: Princeton University Press).

Levy, D.L. and Kolk, A. (2002), 'Strategic Responses to Global Climate Change: Conflicting Pressures on Multinational in the Oil Industry', Business and Politics, 4 (3), pp. 275-300.

Lite, J. (2009), 'Obama Halts Last-minute Bush Regulations’, Scientific American, 21 January.

Marcel, V. (2006), Oil Titans: National Oil Companies in the Middle East (London: Chatham House).

Mattoo, A. and Subramanian, A. (2009), 'From Doha to the Next Breton Woods', Foreign Affairs, 88 (1), pp. 15-26.

Morse, E.L. (1999), ‘A New Political Economy of Oil?’, Journal of International Affairs, 53 (1), pp. 1-29.

Mouawad, J. (2006), ‘Western Firms Feel a Pinch from Oil Nationalism', International Herald Tribune, 7 May.

Myers Jaffe, A. (2007), 'The Changing Role of National Oil Companies in International Energy Markets’, Baker Institute Policy Report, Published by the James A. Baker III Institute for Public Policy of Rice University, no. 35, March.

Myers Jaffe, A. and Soligo, R. (2007), 'IOCs: Investment and Industry Structure', Paper prepared in conjunction with an energy study sponsored by Japan Petroleum Energy Center and the James A. Baker III Institute for Public Policy, Rice University, March. 
Noreng, Ø. (2002), Crude Power: Politics and the Oil Market (London: I.B. Tauris).

Noreng, Ø. (1981), 'State-Owned Oil Companies: Western Europe', in R. Vernon and Y. Aharoni, eds., State-Owned Enterprise in the Western Economies (London: Croom), pp. 13344.

Organization of the Petroleum Exporting Countries (2003), Annual Statistical Bulletin 2002 (Vienna, Austria: Ueberreuter).

Organization of the Petroleum Exporting Countries (2008), Annual Statistical Bulletin 2007 (Vienna, Austria: Ueberreuter).

Oxford Analytica (2008), ‘IOCs Face Increasing NOC Challenge’, 11 September.

Parra, F. (2004), Oil Politics: A Modern History of Petroleum (London, I.B. Tauris).

Pirog, R. (2007), 'The Role of National Oil Companies in the International Oil Market', CRS Report for Congress, 21 August.

Schwartz, N.D. (2006a), ‘A Shell of Itself’, Fortune, 6 March.

Schwartz, N.D. (2006b), 'The Biggest Company in America is also a Big Target', Fortune, 17 April.

Securing America’s Future Energy (2008), ‘Are Oil Companies Liquidating Themselves?’, Intelligence Report, 1 (4), 16 June.

Shapiro, R.J. and Pham, N.D. (2007), 'The Distribution of Ownership of U.S. Oil and Natural Gas Companies', report prepared with support from the American Petroleum Institute (API), September. Available from: http://www.energytomorrow.org/media/resources/r_477.pdf [Accessed 4 Feb 2009].

Shelley, T. (2005), Oil: Politics, Poverty and the Planet (London: Zed Books).

Skjærseth, J.B. and Skodvin, T. (2001), 'Climate Change and the Oil Industry: Common Problems, Different Strategies’, Global Environmental Politics, 1 (4), pp. 43-64.

Starr, R., Newfrock, J. and Delurey, M. (2003), 'Enterprise Resilience: Managing Risk in the Networked Economy’, Strategy and Business, 30, Spring.

Stern, N. (2006), 'Stern Review on the Economics of Climate Change', Her Majesty's Treasury, 30 October.

Stevens, P. (2008), 'National Oil Companies and International Oil Companies in the Middle East: Under the Shadow of Government and the Resource Nationalism Cycle', Journal of World Energy Law \& Business, 1 (1), pp. 5-30.

Stevens, P., ed. (1998), Strategic Positioning in the Oil Industry: Trends and Options (Abu Dhabi: Emirates Center for Strategic Studies and Research). 
Tétreault, M.-A. (1995), The Kuwait Petroleum Corporation and the Economics of the New World Order (Westport, CT: Quorum Books).

van der Linde, C. (2000), The State and the International Oil Market: Competition and the Changing Ownership of Crude Oil Assets (Boston: Kluwer Academic Publishers).

Verleger, Jr., P.K. (2006/2007), 'The Mercedes Model', Newsweek, Special Edition, December-February.

Vernon, R. (1971), Sovereignty at Bay: The Multinational Spread of U.S. Enterprises (New York, Basic Books).

Vivoda, V. (2008), The Return of the Obsolescing Bargain and the Decline of Big Oil: A Study of Bargaining in the Contemporary Oil Industry (Saarbrücken, Germany, Vdm Verlag Dr. Müller).

Wälde, T.W. (2008), 'Renegotiating Acquired Rights in the Oil and Gas Industries: Industry and Political Cycles Meet the Rule of Law’, Journal of World Energy Law \& Business, 1 (1), pp. 55-97.

Williams, J. and Hodge, S.A. (2005), 'Oil Company Profits and Tax Collections: Does the U.S. Need a New Windfall Profits Tax?', The Tax Foundation, Fiscal Facts, no. 41, 9 November.

Wilson III, E.J. (1986), 'The Petro-Political Cycle in World Oil Markets', in R.L. Enders and J. Kim, eds., Energy Resource Development: Politics and Policies (Westport, CT: Greenwood Press), pp. 1-20.

Wilson III, E.J. (1987), 'World Politics and International Energy Markets', International Organization, 41 (1), pp. 125-49.

Xu, Y. (2006), 'China’s Energy Security’, Australian Journal of International Affairs, 60 (2), pp. 265-86.

Yergin, D. (1992), The Prize: The Epic Quest for Oil, Money \& Power (New York, Free Press). 
